\title{
Penerapan Scientific Approach untuk Meningkatkan Literasi Saintifik dalam Domain Kompetensi Siswa SMP pada Topik Kalor
}

\author{
Widi Ilhami Novili1 ${ }^{1, a)}$, Setiya Utari ${ }^{2, b)}$, Duden Saepuzaman ${ }^{3, c)}$ \\ Prodi Pendidikan Fisika FPMIPA UPI, Jl. Dr Setiabudhi No.229, Bandung 40154 \\ Email: ${ }^{\text {a)}}$ widiilhaminovili@gmail.com, ${ }^{\text {b) }}$ setiyautari@yahoo.co.id, ${ }^{c}$ dsaepuzaman@upi.edu
}

\begin{abstract}
Scientific Literacy (SL) is a person's ability to use knowledge and scientific process to understand scientific phenomena in solving a problem or making a decision. However it is known that the SL of Indonesian students are in low grade. There is an indication that the SL is less facilitated in science learning. Capabilities that it is seen difficult associated with evaluating and designing scientific investigations, as well as making the questions for investigation. Quasy-experimental research with one group pretest and posttest design applied in one of the schools in Bandung city through purposive sampling, which consist of 32 students which aim to get the result of the SL after being applied scientific approach to the topic of heat. The instrument uses 20 essays with a reliability of 0.83 . N-gain analysis showed an increase in the domain of competence, that is a competence in explaining scientific phenomena, competence in evaluating and designing of scientific research, as well as the competence to interpret the data and scientific evidence.. Learning with applying scientific approach has been able to increase the competency in the medium category.
\end{abstract}

Keywords: scientific approach, scientific literacy, heat

\begin{abstract}
Abstrak
Literasi Saintifik (LS) merupakan suatu kemampuan seseorang dalam menggunakan pengetahuan dan proses sains untuk memahami fenomena ilmiah dalam memecahkan suatu masalah atau mengambil keputusan. Namun diketahui bahwa LS siswa Indonesia masih rendah. Terdapat indikasi bahwa LS ini kurang terfasilitasi di dalam pembelajaran sains. Kemampuan yang dipandang sulit terkait dengan mengevaluasi dan merancang penyelidikan ilmiah, serta membuat pertanyaan penyelidikan. Penelitian quasy-eksperimen dengan desain one group pretest and posttest diterapkan di salah satu sekolah di kota Bandung melalui purposive sampling dengan jumlah sampel 32 siswa yang bertujuan untuk mendapatkan hasil LS setelah diterapkan scientific approach pada topik kalor. Instrumen menggunakan 20 soal essay dengan reliabilitas 0,83 . Analisis $\mathrm{N}$-gain menunjukkan peningkatan pada domain kompetensi yaitu kompetensi menjelaskan fenomena ilmiah, kompetensi mengevaluasi dan merancang penelitian ilmiah, serta kompetensi menginterpretasikan data dan bukti ilmiah. Pembelajaran dengan scientific approach telah dapat meningkatkan domain kompetensi dalam kategori sedang.
\end{abstract}

Kata-kata kunci: scientific approach, literasi saintifik, kalor 


\section{PENDAHULUAN}

Literasi saintifik dapat didefinisikan sebagai suatu kemampuan seseorang dalam menggunakan pengetahuan dan proses sains untuk memahami fenomena ilmiah dalam memecahkan suatu masalah atau mengambil keputusan. Hal ini senada dengan yang dijelaskan oleh The Organization for Economic Comperation and Development (OECD) mengenai definisi literasi saintifik. Disisi lain, Miller (dalam Hobson 2008) mendefinisikan literasi saintifik sebagai level pemahaman sains dan teknologi yang diperlukan untuk dimanfaatkan pada zaman modern sekarang ini. Dari pendapat tersebut dapat kita ketahui bahwa literasi saintifik memang diharapkan dapat dimiliki siswa di zaman modern ini.

Indonesia merupakan salah satu negara yang mengikuti PISA. Hasil survei literasi saintifik TIMSS (2000-2012) menyatakan bahwa siswa Indonesia pada setiap periode selalu mendapatkan peringkat bawah. Senada dengan hal tersebut, hasil penelitian menunjukkan bahwa pada sampel sebanyak 628 siswa di lima sekolah yang berbeda di Kota Bandung, literasi saintifik siswa pada domain kompetensi masih rendah (Utari 2015).

Isu yang sama ditemukan dari hasil observasi dan wawancara dengan tiga orang guru di salah satu SMP Negeri di Kota Bandung bahwa pembelajaran IPA yang dilakukan di kelas belum memfasilitasi siswa untuk mengembangkan literasi saintifik secara optimal. Hal ini disebabkan oleh beberapa hal. Pertama, pembelajaran IPA yang dilakukan di kelas tidak berangkat dari fenomena-fenomena ilmiah, meskipun sebenarnya pada pembelajaran tersebut terdapat contoh fenomena ilmiahnya, sehingga tidak ada kesempatan siswa untuk menghasilkan pertanyaan penyelidikan. Kedua, guru kurang membelajarkan kegiatan eksperimen. Siswa sangat jarang diberikan kegiatan eksperimen, meskipun kegiatan tersebut dapat melatihkan siswa dalam mengevaluasi dan merancang penelitian ilmiah. Hal ini didukung oleh pendapat salah satu guru IPA di sekolah tersebut yang menyatakan bahwa ketika diadakan kegiatan eksperimen, kegiatan tersebut lebih bersifat cookbook dan tidak dilatihkan mengidentifikasi variabel-variabel eksperimen. Ketiga, siswa kurang dilatihkan mengerjakan soal yang mengedepankan literasi saintifik yang terdapat kaitannya dengan kehidupan nyata, sehingga kurang melatihkan penggunaan pengetahuan dan kemampuan menerapkan konsep yang telah siswa pelajari.

Berdasarkan hal tersebut, maka perlu dilakukan penelitian untuk memperbaiki proses pembelajaran di sekolah. Salah satu alternatif solusinya adalah dengan menerapkan scientific approach dalam pembelajaran. Pembelajaran dengan scientific approach ini dipilih karena dalam proses pembelajarannya melibatkan kemampuan siswa secara maksimal dalam membangun konsep, hukum atau prinsip melalui tahap mengamati (untuk mengidentifikasi atau menemukan masalah), merumuskan masalah, mengajukan atau merumuskan hipotesis, mengumpulkan data dengan berbagai teknik, menganalisis data, menarik kesimpulan dan mengomunikasikan konsep, hukum atau prinsip yang ditemukan (Kemendikbud 2013). Hal ini sejalan dengan apa yang dituntut dalam literasi saintifik.

Berdasarkan uraian di atas, maka peneliti tertarik melakukan penelitian dengan menerapkan scientific approach pada pembelajaran IPA (fisika) untuk meningkatkan literasi saintifik siswa SMP dalam domain kompetensi pada topik kalor.

\section{METODE PENELITIAN}

Metode penelitian yang digunakan adalah quasy-experimental dengan desain one group pretest and posttest. Pada penelitian ini, tahap awalnya siswa diberikan pretest untuk mengukur literasi saintifik awal siswa. Setelah itu, siswa diberikan penerapan Rencana Pelaksanaan Pembelajaran (RPP) dengan menggunakan scientific approach. Kemudian pada tahap akhir, siswa diberikan posttest untuk mengukur literasi saintifik siswa setelah dilakukan pembelajaran.

Instrumen penelitian berupa instrumen tes literasi saintifik dan lembar observasi keterlaksanaan scientific approach. Instrumen tes literasi saintifik yang diberikan berupa soal esay berjumlah 20 soal mencakup domain kompetensi menurut PISA 2015.

Teknik pengolahan data literasi saintifik dilakukan dengan analisis N-gain untuk mengetahui peningkatan literasi saintifik siswa setelah pembelajaran dilakukan, uji post hoc BNt atau LSD untuk

e-Jurnal: http://doi.org/10.21009/1 
mengetahui apakah rata-rata dua perlakuan berbeda secara statistik atau tidak, dan effect size untuk mengetahui seberapa besar pengaruh scientific approach dalam melatihkan literasi saintifik siswa. Sedangkan untuk menilai keterlaksanaan scientific approach digunakan rumus sebagai berikut :

$$
P(\%)=\frac{\sum \text { Skorhasildservasi }}{\sum \text { skortotal }} \times 100 \%
$$

TABEL 1. Interpretasi Keterlaksanaan Pembelajaran

\begin{tabular}{cc}
\hline KM (\%) & Kriteria \\
\hline $0-20$ & Sangat tidak terlaksana \\
$21-40$ & Tidak terlaksana \\
$41-60$ & Kurang terlaksana \\
$61-80$ & Terlaksana \\
$81-100$ & Sangat terlaksana \\
\hline
\end{tabular}

(Riduwan 2010)

\section{HASIL DAN PEMBAHASAN}

\section{Literasi Saintifik Siswa pada Domain Kompetensi}

Domain kompetensi terbagi menjadi tiga sub domain, yaitu menjelaskan fenomena ilmiah, mengevaluasi dan merancang penelitian ilmiah, serta menginterpretasikan data dan bukti ilmiah. Untuk menganalisis peningkatan yang terjadi pada literasi saintifik siswa setelah diterapkan scientific approach, maka dilakukan analisis dengan N-Gain. Berikut ini hasil yang didapat pada domain kompetensi.

TABEL 2. Literasi Saintifik pada Domain Kompetensi

\begin{tabular}{|c|c|c|c|c|c|c|}
\hline \multirow[b]{2}{*}{ No. } & \multirow[b]{2}{*}{ Sub Domain Kompetensi } & \multicolumn{2}{|c|}{ Persentase (\%) } & \multirow[b]{2}{*}{$<\mathbf{g}>$} & \multirow[b]{2}{*}{$<\mathrm{g}>(\%)$} & \multirow[b]{2}{*}{ Kategori } \\
\hline & & Pretest & Postest & & & \\
\hline 1. & $\begin{array}{l}\text { Menjelaskan fenomena } \\
\text { ilmiah }\end{array}$ & 26,67 & 69,50 & 0,58 & 58 & Sedang \\
\hline 2. & $\begin{array}{l}\text { Mengevaluasi dan } \\
\text { merancang penelitian } \\
\text { ilmiah }\end{array}$ & 26,89 & 55,33 & 0,39 & 39 & Sedang \\
\hline 3. & $\begin{array}{l}\text { Menginterpretasikan data } \\
\text { dan bukti ilmiah }\end{array}$ & 28,44 & 66,00 & 0,52 & 52 & Sedang \\
\hline
\end{tabular}

Apabila dari tabel 2 diinterpretasikan dalam diagram batang, maka diperoleh hasil sebagai berikut: 


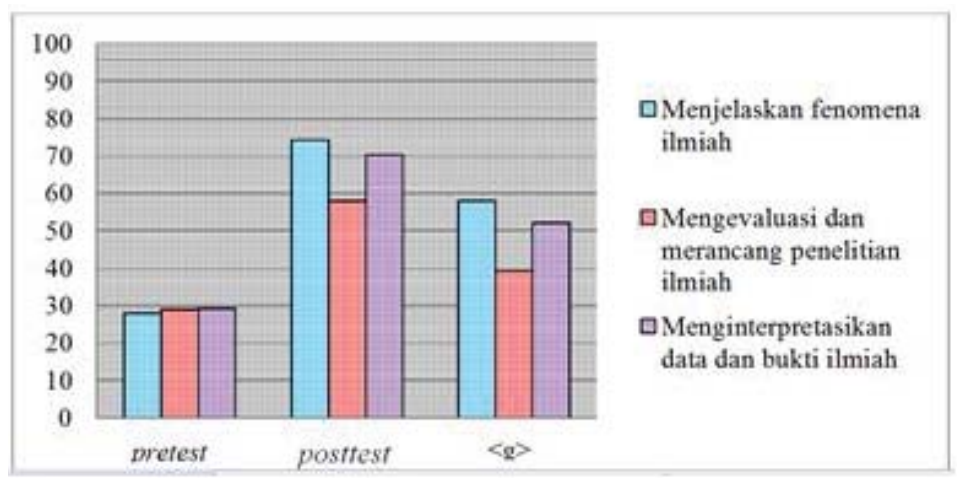

Berdasarkan data di atas, diketahui bahwa domain kompetensi literasi saintifik siswa mengalami peningkatan setelah dilakukan pembelajaran dengan scientific approach dan secara keseluruhan mengalami peningkatan dalam kategori sedang. Maka dari itu, untuk mengetahui peningkatan NGain manakah yang memiliki perbedaan signifikan dan untuk mengetahui seberapa besar pengaruh scientific approach dalam melatihkan literasi saintifik pada domain kompetensi, maka digunakan pengolahan dengan post hoc dan effect size yang hasilnya dapat dilihat pada tabel di berikut:

TABEL 3. Scientific approach dalam Melatihkan Domain Kompetensi

\begin{tabular}{lcccc}
\hline No. & $\begin{array}{c}\text { Sub Domain } \\
\text { Kompetensi }\end{array}$ & $\begin{array}{c}\text { Notasi } \\
\text { Post Hoc }\end{array}$ & Effect Size & Kategori \\
\hline 1. & $\begin{array}{c}\text { Menjelaskan fenomena } \\
\text { ilmiah }\end{array}$ & $0,58^{\mathrm{a}}$ & 2,10 & Large effect \\
& $\begin{array}{c}\text { Mengevaluasi dan } \\
\text { merancang penelitian } \\
\text { ilmiah }\end{array}$ & $0,39^{\mathrm{a}}$ & 1,36 & Large effect \\
2. & & & \\
3. & $\begin{array}{c}\text { Menginterpretasikan data } \\
\text { dan bukti ilmiah }\end{array}$ & $0,52^{\mathrm{a}}$ & 1,75 & Large effect \\
\hline
\end{tabular}

Berdasarkan data di atas, diketahui bahwa dari ketiga sub domain kompetensi tidak ada yang memiliki perbedaan signifikan. Hal ini dapat dilihat dari notasi post hoc yang menunjukkan bahwa ketiga sub domain tersebut memiliki notasi yang sama. Selain itu, hasil effect size pun menunjukkan bahwa scintific approach memiliki pengaruh yang besar dalam melatihkan ketiga sub domain kompetensi literasi saintifik tersebut.

Dalam penelitian ini, fenomena-fenomena ilmiah yang diberikan adalah fenomena yang sering dijumpai siswa dalam kehidupan sehari-hari. Apabila dilihat dari nilai N-Gain yang diperoleh, kompetensi menjelaskan fenomena ilmiah memperoleh nilai peningkatan sebesar 0,58. Hal ini dapat terjadi karena kompetensi menjelaskan fenomena ilmiah selalu dilatihkan pada setiap tahapan pembelajaran scientific approach. Hal tersebut didukung dengan hasil wawancara siswa yang menyebutkan bahwa fenomena-fenomena ilmiah yang diberikan sudah tidak asing dan pernah siswa lihat, sehingga siswa dapat mengingat dan menerapkan konsep dasar pada fenomena ilmiah yang diberikan. Selain itu, dukungan lainnya diperoleh dari hasil penelitian PISA (2012) yang menyebutkan bahwa sekitar 23,3\% siswa Indonesia telah mempunyai kompetensi untuk menjelaskan fennomena ilmiah.

Kompetensi selanjutnya adalah mengevaluasi dan merancang penelitian ilmiah. Pada kompetensi ini, siswa dituntut untuk mampu merancang prosedur eksperimen sesuai dengan kasus yang diberikan mengenai pengaruh kalor terhadap perubahan suhu, pengaruh kalor terhadap perubahan wujud zat, dan perpindahan kalor. Apabila dilihat dari perolehan nilai N-Gain yang didapat, peningkatan pada 
kompetensi mengevaluasi dan merancang penelitian ilmiah ini memperoleh nilai sebesar 0,39. Hal ini dapat terjadi karena ketika dilihat dari tahapan pembelajaran scientific approach, kompetensi mengevaluasi dan merancang penelitian ilmiah hanya dilatihkan dalam tiga tahapan pembelajaran. Faktor lain yang menyebabkan peningkatan ini rendah karena sebelumnya siswa tidak pernah diminta untuk membuat rancangan prosedur eksperimen, sehingga ketika pretest siswa belum mengetahui bagaimana seharusnya merancang prosedur eksperimen. Dukungan lain diperoleh dari hasil peneliitian PISA (2012) yang menunjukkan bahwa siswa Indonesia belum dapat mencapai kompetensi mengevaluasi dan merancang penelitian ilmiah. Hal tersebut dikuatkan oleh NCES (2012) yang membagi level pencapaian literasi saintifik ke dalam enam level. Menurut NCES (2012), kompetensi mengevaluasi dan merancang penelitian ilmiah ini berada pada level 6, yaitu siswa dituntut untuk mampu mengidentifikasi, menjelaskan, mengevaluasi, dan menerapkan pengetahuan ilmiah dan pengetahuan lainnya tentang kehidupan sehari-hari yang kompleks. Hal ini menunjukkan bahwa memang kompetensi mengevaluasi dan merancang penelitian ilmiah dangat sulit. Maka dari itu, untuk mengatasi hal ini guru harus melatihkan cara-cara mengevaluasi hasil eksperimen misalnya dengan melakukan modeling seperti yang diungkapkan Heller (1999) yang menyatakan bahwa modeling adalah suatu cara untuk melatihkan siswa belajar berdasarkan bimbingan dari guru. Dari pernyataan Heller ini, dapat diambil kesimpulan bahwa guru harus memberikan contoh terlebih dahulu pada siswa agar siswa dapat belajar dari hasil bimbingan guru tersebut.

Kompetensi ketiga adalah menginterpretasikan data dan bukti ilmiah. Kompetensi ini menuntut siswa untuk dapat mengubah satu bentuk representasi ke dalam bentuk yang lain. Berdasarkan hasil wawancara didapatkan bahwa untuk mengubah data dari bentuk tabel ke bentuk grafik tidak terlalu sulit, karena jika memahami tabel data tersebut, maka untuk mengubahnya ke bentuk grafik pun lebih mudah. Hal ini pun didukung oleh PISA (2012) yang menunjukkan bahwa 6,5\% sudah dapat menginterpretasikan data dan bukti ilmiah. Hal ini juga dikuatkan dengan level dalam NCES (2012) yang menunjukkan bahwa kompetensi menginterpretasikan data dan bukti ilmiah ini berada pada level 3, yaitu siswa dituntut untuk mampu mengidentifikasi dan memahami masalah ilmiah dalam berbagai konteks.

Secara keseluruhan, penerapan scientific approach dalam melatihkan literasi saintifik pada domainn kompetensi. Hal ini didukung dengan perolehan data yang menunjukkan peningkatan literasi saintifik pada setiap sub domain kompetensi.

\section{Keterlaksanaan Scientific approach}

Untuk menilai keterlaksanaan scientific approach pada pembelajaran, maka dilakukan observasi keterlaksanaan pembelajaran scientific approach yang dilakukan oleh dua orang observer. Penilaian yang dilakukan dimulai dari kegiatan pendahuluan, kegiatan inti, dan kegiatan penutup. Penilaian ini berlangsung selama tiga pertemuan. Dari hasil observasi yang dilakukan oleh dua orang observer, diperoleh rerata keterlaksanaan aktivitas guru sebesar 96,43\%, sedangkan rata-rata keterlaksanaan aktivitas siswa sebesar $84,84 \%$. Hal tersebut menunjukkan bahwa secara umum proses pembelajaran dalam scientific approach terlaksana. Hasil observasi menunjukkan bahwa baik keterlaksanaan aktivitas guru maupun siswa mengalami fluktuasi dari pertemuan 1 sampai pertemuan 3 .

Secara keseluruhan, penerapan scientific approach dapat melatihkan literasi saintifik siswa pada domain kompetensi dan domain pengetahuan pada topik kalor. Pertama, tahap mengamati yaitu siswa diberikan fenomena ilmiah tentang pengaruh kalor terhadap perubahan suhu, pengaruh kalor terhadap perubahan wujud, dan perpindahan kalor. Hal ini memberikan kesempatan bagi siswa untuk memahami konsep pada setiap pembahasan tersebut dengan lebih mudah, sehingga siswa mampu menjelaskan fenomena ilmiah yang teramati. Kedua, tahap menanya yaitu memberikan kesempatan siswa untuk mengidentifikasi masalah pada fenomena ilmiah yang telah diamati dan menuangkan hasil identifikasi tersebut dalam bentuk pertanyaan penelitian. Hal ini menunjukkan bahwa tahap mengamati dan menanya dapat melatihkan kompetensi menjelaskan fenomena ilmiah. Ketiga, tahap mengumpulkan informasi yaitu melatihkan siswa untuk mengidentifikasi variabel-variabel eksperimen serta merancang prosedur eksperimen untuk mendapatkan data. Tidak hanya itu, pada tahap ini pun siswa diberikan kesempatan untuk mencari dari sumber/referensi lain, sehingga melatihkan kompetensi menjelaskan fenomena ilmiah dan menginterpretasikan data dan bukti ilmiah. 
Keempat, tahap mengasosiasi yaitu melatihkan siswa untuk menganalisis data yang telah diperolehnya. Pada tahap ini pun siswa dilatihkan untuk menganalisis hubungan antar variabel dan mengubah satu bentuk representasi ke bentuk representasi lain. Hal ini menunjukkan bahwa tahap mengumpulkan informasi dan mengasosiasi dapat melatihkan kompetensi menjelaskan fenomena ilmiah, mengevaluasi dan merancang penelitian ilmiah, serta kompetensi menginterpretasikan data dan bukti ilmiah. Kelima, tahap mengomunikasikan yaitu melatihkan siswa dalam memberikan pendapat dan pertimbngannya.

Tahap pembelajaran dalam scientific approach ini sangat banyak melibatkan siswa dimulai dari tahap mengamati, menanya, mengumpulkan informasi, mengasosiasi, serta mengomunikasikan. Hal ini dapat membantu siswa membangun konsepsi pengetahuannya, sehingga siswa dapat menghubungkan pengetahuan yang baru dengan pengetahuan yang telah dimilikinya. Hal tersebut senada dengan pendapat Piaget yang menyatakan bahwa pengetahuan merupakan hasil berpikir manusia (organizing and adapting) yang direkonstruksi dari proses pengalamannya secara terus menerus dan setiap kali dapat terjadi rekonstruksi karena adanya pemahaman baru yang diperoleh melalui proses adaptasi belajar (Haristy 2012).

\section{SIMPULAN}

Berdasarkan hasil dan pembahasan penelitian terkait penerapan scientific approach dalam upaya melatihkan literasi saintifik, didapatkan kesimpulan yaitu secara keseluruhan domain kompetensi mengalami peningkatan dalam kategori sedang. Selain itu, dilihat dari keterlaksanaan scientific approach dalam pembelajaran IPA pada topik kalor, secara umum termasuk dalam kategori sangat terlaksana.

\section{UCAPAN TERIMAKASIH}

Penulis mengucapkan terima kasih kepada semua pihak yang telah membantu kelancaran penulisan penelitian ini.

\section{REFERENSI}

Haristy, D.R. (2012) Pembelajaran Berbasis Literasi saintifik pada Materi Larutan Elektrolit dan Non Elektrolit di SMA Negeri 1 Pontianak. Skripsi Program Studi Pendidikan Kimia FKIP Untan: Tidak Diterbitkan.

Heller, P \& K. Heller. 1999. Problem-Solving Labs, in Cooperetive Group Problem Solving in Physics, Research Report. University of Minnesota.

Hobson. (2008). The Surprising Effectiveness of College Scientific Literacy Course. [Online]. Tersedia http://ace.unl.edu/archive/ScientificLiteracy_Hobson,A.pdf

Kementrian Pendidikan dan Kebudayaan RI. (2013). Lampiran IV Peraturan Menteri Pendidikan dan Kebudayaan Republik Indonesia Nomor 81A Tahun 2013 Tentang Implementasi Kurikulum Pedoman Umum Pembelajaran. Jakarta: Kemendikbud.

NCES. (2012). The Conditional of Education 2012. [Online]. Tersedia : http://nces.ed.gov/pubsearch/pubsinfo.asp?pubid=2012045s

Utari, Setiya. dkk. (2015). Designing Science Learning for Training Students' Science Literacies at Junior High School Level. [Online]. Tersedia: https://www.researchgate.net/publication/281610756

OECD. (2003). Literacy Skills for the World of Tomorrow: Further Result from PISA 2000.

[Online]. Tersedia: http://www.pisa.oecd.org/Docs/Download/PISAplus_eng01.pdf

Riduwan, (2010). Skala Pengukuran Variabel-Variabel Penelitian. Bandung: Alfabeta. 